\title{
The Fragility of Labour Corridors to Costa Rica and the United States: Precarious Migrant Workers in Central America ${ }^{1}$
}

\author{
Abelardo Morales-Gamboa, Universidad Nacional, Costa Rica
}

\begin{abstract}
Central American migration flows take place mostly through two main corridors: the northern corridor to the United States, and the southern corridor to Costa Rica. Using the concept of fragility, in this article I analyse how migration combines the precarity and vulnerability that Central American workers face, both in their home country and in the corridors toward the destination labour markets. Their movements and the conditions they encounter reflect a new scale of local and transnational labour relationships. Migrant workers constitute a segment of the workforce in transnational corridors, which circulates between several informal activities but also among key sectors of the formal economy; the latter often takes advantage of their social, occupational and even legal difficulties.
\end{abstract}

\section{Keywords}

Central America; migrant workers; labour markets; informal economy; labour corridors

\section{Introduction}

Central America is a small isthmus in the middle of the Americas, comprising just 523000 square kilometres. Despite its small size, it is divided into seven national territories rich in environmental, social and political diversity. Within the region, labour market conditions are closely tied to the characteristics of labour migration. While there is thus a critical regional component to the composition and performance of labour markets, most studies have tended to centre their analyses on individual national labour markets or on the relationship between a sending and a receiving country. ${ }^{2}$ Moreover, out of the very large body of literature on Central American migration, only a few studies have brought to bear a comprehensive regional perspective (Castillo, 2000; Cortés, 2003; Morales-Gamboa, 2007, 2010, 2013, 2014, 2020; Marroquín, 2014; Heredia, 2016; Sandoval, 2016; Viales and Díaz, 2016). The result has been a paucity of studies focusing on labour migration

\footnotetext{
${ }_{1}^{1}$ The author appreciates the comments of Ruth Felder and Viviana Patroni to the previous versions of the article, although he acknowledges that he is solely responsible for the final text.

${ }^{2}$ In the case of Central America, Salvadoran and Guatemalan migration to the United States has been a key area of research (Menjivar, 2000; PNUD, 2005). Similarly, the migration of Nicaraguans to Costa Rica has also been the subject of a large number of studies (Morales and Valverde, 2002; Morales-Gamboa, 2008; Chaves-Groh, 2017). Other key themes in the literature have been the micro-scale analysis of gender, ethnicity, remittances and other local dimensions (Camus, 2007; García and Orozco, 2009). The contributions of Cortés (2003) and Viales and Díaz (2016) are central in the development of a regional perspective under a transnational approach.
} 
(Sandoval, 2007; Acuña et al., 2011; Orrenius and Zavodny, 2015), its connection to labour markets in the region and the conditions generating informality and precarity within migration corridors (Morales-Gamboa, 2013; OIT, 2016).

There is a broad literature that studies migration from the perspective of transnationalism (Bash, Glick Schiller and Szanton Blanc, 1994; Vertovec, 2004; Castles, 2009; Glick Shiller, 2014), but in research on Central America there has not been sufficient attention to a transnational dimension, that is, a consideration to the way in which migration is framed within a territoriality transcending national borders and societies (Pries, 2001, 2017). I argue that a comprehensive regional perspective is essential to understand the historical and structural conditions that heighten both the vulnerability of Central American migrant workers and the dangers they confront within the two corridors I analyse in this paper.

Central American migration is not new. Migratory corridors between neighbouring countries go as back as far as the late nineteenth century; they have been fuelled by intraregional shifts in labour demand as well as political conflict and civil wars (Morales-Gamboa, 2007). The process under analysis here has to be situated in the context of the historical political instability in the region (with the exception of Costa Rica) and of the civil wars in Nicaragua, Guatemala and El Salvador during the 1980s. The peace agreements signed by governments and guerrillas from the 1990s onwards created conditions for economic changes that were expected to transform backward and unequal societies. Instead, as Robinson (2003) puts it, these changes were the starting point of neoliberal restructuring and the redefinition of the transnational model of development in the region, in which the United States and its institutions played a preponderant role. The growth of a precarious migrant labour supply was one of its expressions.

The fragile situation migrant workers confront in their countries of origin - long-term structural inequalities, political instability, the effects of the climate crisis, widespread insecurity and crime, as well as the response of the national states to these challenges - and the precarious working conditions and strong migration control policies in their destination countries are the new characteristics of high-risk or survival migration. The notion of survival migration was proposed by Betts (2013: 23) in his study of Sub-Saharan Africa to explain the migration conditions of "persons who are outside their country of origin because of an existential threat for which they have no access to a domestic remedy or resolution". For these migrants, the deprivation of basic human rights becomes the origin of the loss of other rights. ${ }^{3}$ The concept does not focus on a particular cause of displacement, but rather on the relationship between multiple causes as indicated above. In this article I use the notion of survival migration to explore the conditions of labour migrants within the two main corridors in the Central American region: the corridor to the United States and the corridor to Costa Rica.

Migration studies examine the geography, relations and flows between migrant-sending and migrant-receiving countries as components of the migration system (Durand, 2016). Work and its transnational connections are not always well investigated in such studies, despite constituting one of the main drivers of the migration system. Moreover, while the United States, as the main destination country, has been at the core of studies on the migration system oriented towards North America, ${ }^{4}$ analysts have suggested addressing subsystems and migratory flows as a way to more accurately classify the spatial variety of increasingly dense and diverse patterns of migration (Pandit,

\footnotetext{
3 As Betts (2013: 3) points out, these migrants "are not fleeing state persecution, though many are fleeing state incompetence".

${ }^{4}$ This system also includes Canada and Mexico as destination countries, although Mexico is the most important and critical route of the migration from the rest of the hemisphere.
} 
1994; Bakewell, 2014).

A regional perspective to the study of migration exposes some of the shortcomings in these approaches, suggesting that dividing the system into subsystems does not necessarily provide greater conceptual clarity. To remedy this limitation, I use the term corridors to identify components of the migration system that can help us understand the flows and dynamics that develop across the varied geographic and social scales of the migratory field. The concept of corridor does not replace the category of migration system; instead it adds a dimension related to the transnational connection that labour mobility produces. A migratory corridor includes, first, a spatial dimension, based on the territories (regional, national or local), routes, flows and trajectories where labour migration is configured. Second, corridors include a regulatory dimension, comprised of the mechanisms that regulate migratory flows and labour force mobility. Finally, both the spatial and normative characteristics of the corridor shape not only the possibilities of mobility but also the conditions under which labour is absorbed in the destination labour markets. This is the labour dimension of corridors. Each of these three dimensions can be studied in three distinct moments: origin, transit and destination. Unlike the concept of labour market, which is generally considered only at the national level, the concept of the labour corridor allows us to study the social processes that result from transnational interactions - produced by labour mobility - between territories, markets and regulatory mechanisms. From this point of view, the conditions responsible for exploitation - in this case, of the migrant labour force (Pröbsting, 2015) - are not only a product of migrants' destination labour markets but are shaped throughout the corridors, including the territories of origin and of transit. The cheapening of migrants' labour resulting from the devaluation of rights starts before this labour force enters the direct circuits of the relation between capital and labour in the destination country.

While the concept of fragility has been used in studies that examine the relationship between climate crisis and other similar threats to social and political stability (Smith and Vivekananda, 2009; Nagarajan et al., 2018), or to address the notion of "fragile states" as a synonym for "failed states" (Chestermann, Ignatieff and Takur, 2005), the concept has received much less attention in the broader social science literature. Some recent studies address urban violence as an expression of fragility (Muggah, 2014; Koonings and Kruijt, 2015). Muggah (2014) relates the concept to urban areas where insecurity, violence and other forms of social disintegration persist, these problems being in turn related to a breakdown of norms and social pacts.

Marc et al. (2013: 13) offer another definition of fragility, as

... a problem not only of state capacity, but also of dysfunctional relationships across groups in society, including the relationships of different groups with the state. Rather than a static condition, fragility is better conceptualized as a dynamic continuum, along which societies can experience extreme state failure and violent conflict at one end and a more cohesive society moving up the continuum.

I use the notion of fragility to describe the outcome of a set of spatial, social and political conditions in a territory which increase both migrants' vulnerabilities and their labour precarity. Fragility is related to the insufficient development of capacities for counteracting the negative or perverse effects of such changes upon a territory, upon the population that occupies it, and upon the ways of life constructed within it. The notion of fragility, with its multicausal nature, is useful to study survival migration, as the deprivation of the basic labour rights in migrant workers' countries of origin becomes compounded by the accumulation of other deprivations that accompany these workers as they become part of region's migrant labour force (Betts, 2013; Hoeffler, 2013; MartinShields, 2017). 
Since the mid-1990s, I have conducted surveys in Nicaragua and Costa Rica, and semistructured interviews with public officials, state representatives, non-governmental organisations, international agencies, migrant workers, employees, recruiters and other specialised informants in all the Central American countries. The results of these studies have allowed me to validate the thesis of the fragility of intraregional migration corridors and to elucidate the workings of an informal regional labour market sustained through the flow of migrant workers (Morales-Gamboa and Castro-Valverde, 2002; Morales-Gamboa, 2007, 2010, 2013). From this regional perspective, I also studied the characteristics of the migration to the United States (Morales-Gamboa, 2020). Political instability, social inequality and deprivation of rights cause labour migration in the region. These conditions do not operate in isolation in each country of origin but together they explain fragility as a common characteristic of migration, not only on a national scale but also a regional one.

In this article, I aim to show how migration integrates the vulnerability and exclusion that Central American workers face in their labour markets of origin as well as in the corridors. Corridors are a new dimension of labour conditions at both local and transnational scales. They are spaces in which the informalisation of labour markets and the irregular migration status of a large number of migrant workers produce a shift in the conditions of labour force exploitation from the local to the transnational scale. In other words, the existing fragilities in the domestic sphere acquire new forms and dimensions within transnational workplaces. Despite the lack of recognition, migrant workers are an important segment of labour, who circulate between several informal activities but also among key sectors of the formal economy that take advantage of their social, occupational and even legal disadvantages.

In order to connect the analysis of fragility and of labour corridors, I start by hypothesising that fragility manifests itself through the three dimensions mentioned before: spatial, regulatory and labour fragilities expressed in a continuum within the territories of origin, transit and destination. Before moving on to the analysis of these dimensions, I contextualise the process of creation of a precarious labour force in the region: I first look at the changes in labour markets brought about by the economic structural changes and the expansion of informality from the 1990s on. I base this analysis on available quantitative data on each of the countries of the region and my own research on migration from a regional perspective. Second, I use quantitative data to present an overview of Central American migration to several world destinations within and beyond the region. ${ }^{5}$ With that as the background, in the following sections I examine corridors as spaces for the constitution of precarious migrant labour and their three dimensions: spatial, regulatory and labour. I conclude with some notes on the implications of the analysis of these corridors for the conceptualisation of the precarity that regional migrant workers confront.

\section{Domestic Labour Markets and Labour Precarity in Central America}

As I mentioned before, the domestic fragility of labour markets in Central America has been caused by the joint effects of the transformation of agriculture, changes in the industrial structure and the deregulation of labour relations, including the growth of the maquila sector, extractive activities and the service sector. These conditions have been compounded by the ongoing political instability

\footnotetext{
${ }^{5}$ For comparative purposes, I have relied on the United Nations Department of Economic and Social Affairs (UNDESA, 2020) database. This database gathers statistics from recipient countries but does not include international migrants who are temporarily in corridors or transit countries. For example, there is an information gap about the number of Central American in transit through Mexico.
} 
since the 1990s. Furthermore, extractive activities related to mining, hydroelectricity, tourism and agribusiness have transformed the economies of some countries in the region (Alvarez et al., 2015). However, far from providing significant new sources of work, economic expansion has led to internal displacement and migration.

Until 1990, the national economies of some Central American countries depended on agricultural production, whose added value to the Gross Domestic Product was close to 20 per cent as a regional average (CEPAL, 2014; World Bank, 2020a). Guatemala, Honduras and Nicaragua were the countries that most depended on agricultural activity (Table 1). After the agreements that put an end to the civil wars, a series of reforms to reduce the local economies' dependence on export monocultures and promote industrial maquila production was initiated. During the 1990s, the international coffee market crisis and the drop in production of staple grains, exacerbated by natural disasters and global warming, revealed the fragility of Central American agriculture, which had been the historical refuge of the majority of the labour force (MoralesGamboa, 2014).

As a result, production in this sector fell sharply throughout that decade, with markedly high impacts in El Salvador, Guatemala, Honduras and Costa Rica. The country where agriculture first declined was El Salvador, with an average decline of more than 50 per cent in the decade following the civil war (1981-1992), while the average decrease in all four countries mentioned above exceeded 45 per cent between 1990 and 2000. Although the decline slowed down after 2000, the crisis of agriculture persisted. In 2019, its aggregate value remained negative in every single country in the region.

Table 1.

Central America: aggregate value of agriculture as percentage of GDP and variations between decades (1990-2000 and 2010-2019)

\begin{tabular}{|l|c|c|c|c|c|c|}
\hline & $\mathbf{1 9 9 0}$ & $\mathbf{2 0 0 0}$ & $\begin{array}{c}\text { \% } \\
\text { Variation } \\
\mathbf{1 9 9 0 - 2 0 0 0}\end{array}$ & $\mathbf{2 0 1 0}$ & $\mathbf{2 0 1 9}$ & $\begin{array}{c}\text { \% } \\
\text { Variation } \\
\mathbf{2 0 1 0 - 2 0 1 9}\end{array}$ \\
\hline Belize & 17.3 & 14.7 & -15.1 & 11.7 & 9.6 & -18.0 \\
\hline Costa Rica & 15.8 & 9.3 & -41.2 & 6.6 & 4.2 & -35.6 \\
\hline El Salvador & 16.0 & 7.2 & -55.2 & 7.0 & 5.1 & -27.2 \\
\hline Guatemala & 25.9 & 13.9 & -46.1 & 11.1 & 9.4 & -15.3 \\
\hline Honduras & 24.2 & 14.4 & -40.6 & 11.6 & 10.7 & -7.5 \\
\hline Nicaragua* & 19.0 & 17.8 & -6.6 & 17.0 & 15.4 & -9.2 \\
\hline Panama & 8.1 & 6.3 & -22.1 & 3.6 & 2.1 & -41.2 \\
\hline
\end{tabular}

Source: World Bank (2020a).

* Nicaragua lacks data for 1990, thus the figures used here are from 1994.

The immediate and long-term result of this process was the formation of surplus rural labour and the displacement of workers from agriculture. At a time when all countries were deindustrialising, most of the uprooted labour force from the countryside was unable to enter other labour market segments, except for some workers drawn to manufacturing in the duty-free export zones. This model of production, known as the maquila industry, depends on the import of raw materials, uses few local inputs and is exempt from paying tariffs in the country where it is established, but it is an industry that relies heavily on labour. In Central America, this labour is largely female and young 
(Maquila Solidarity Network, 2016).

The countries hardest hit by the loss of jobs in agriculture were El Salvador, Guatemala and Honduras, but the impacts have differed widely in the different countries. In northern Central America, the precipitous drop in agricultural employment has been one of the main causes of international migration. In Costa Rica, agriculture had already been declining since 1982 - the last year in which the sector contributed one-quarter of the country's GDP - to eventually dip below 5 per cent in 2019. Interestingly, after agricultural employment fell below 10 per cent of total employment in 2013, agricultural worker recruitment began to grow again over the next six years, as it did in Nicaragua, making these countries the exceptions in the region (see Figure 1). Costa Rica remains the only country in the region where the agricultural labour market depends on the supply of foreign labour. Nicaragua is the only other country in Central America to have recovered jobs in agriculture in the 2010-2019 period, but this recovery has not been sufficient to retain the labour force or prevent it from migrating.

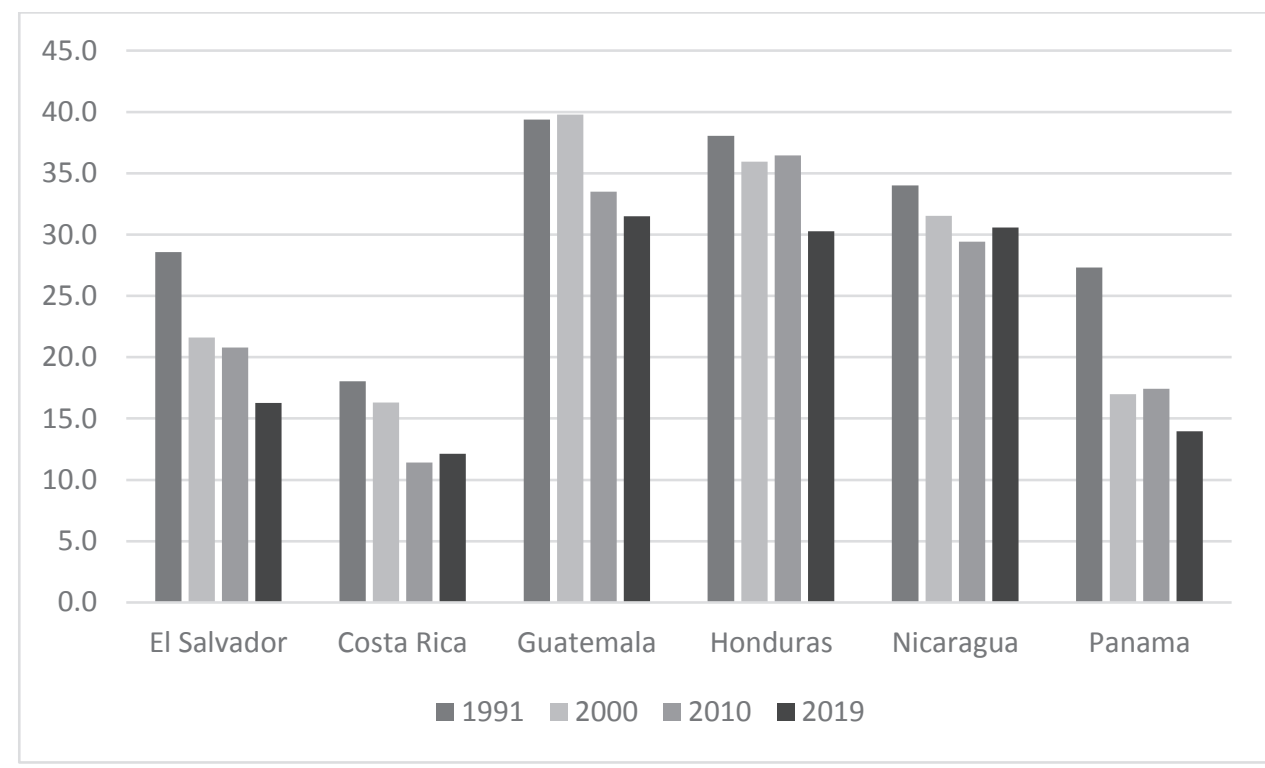

Source: World Bank (2020b).

Figure 1. Central America: employment in agriculture as a percentage of total employment

The service sector became a massive source of employment in all countries. On average, the sector concentrates the greatest volume of jobs in the domestic markets, more than manufacturing and agriculture, representing an average of 58.4 per cent of all jobs in 2019 throughout the region. A significant increase in informal employment has accompanied job growth in this sector. Since the 1990s, informal jobs in informal trade, including street vending, have served as a sanctuary for workers displaced from agriculture and industry. Although there are also significant percentages of informal workers in both agriculture and industry, where self-employed and family workers are concentrated, informal services and commerce tend to constitute refuges for low-skilled workers, immigrants, women and indigenous workers to survive in the face of unemployment or precarious work. 


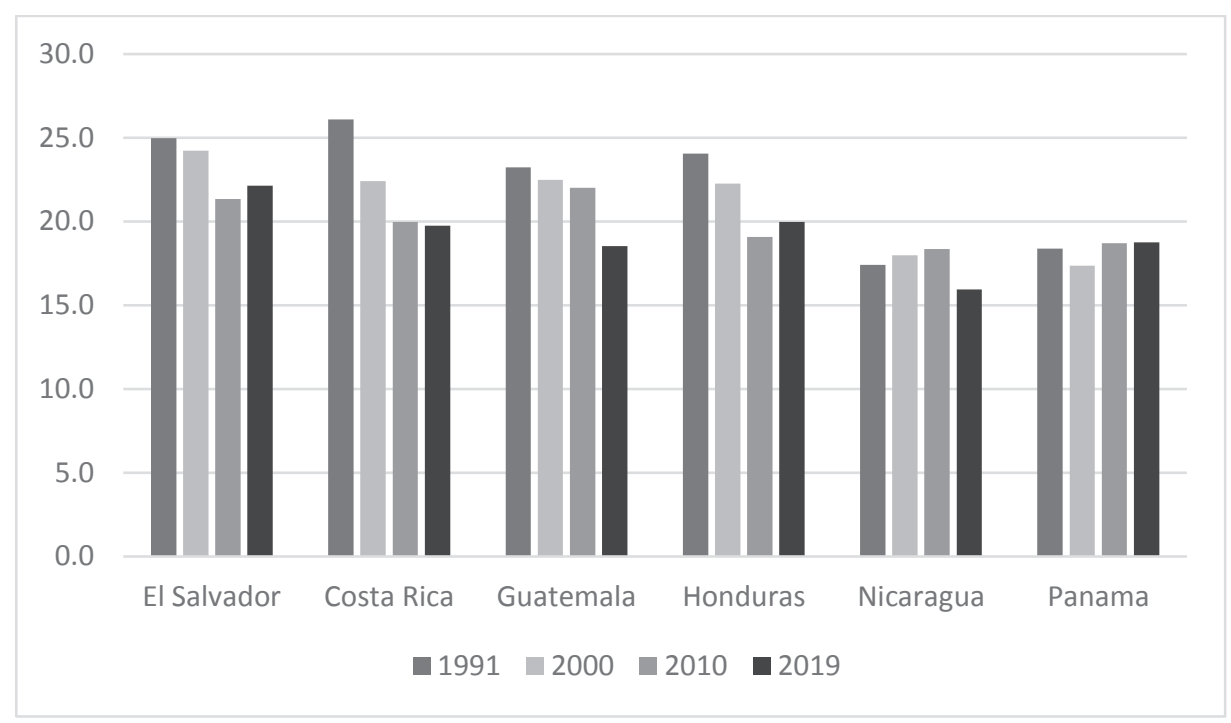

Source: World Bank (2020c).

Figure 2. Central America: employment in industry as a percentage of total employment

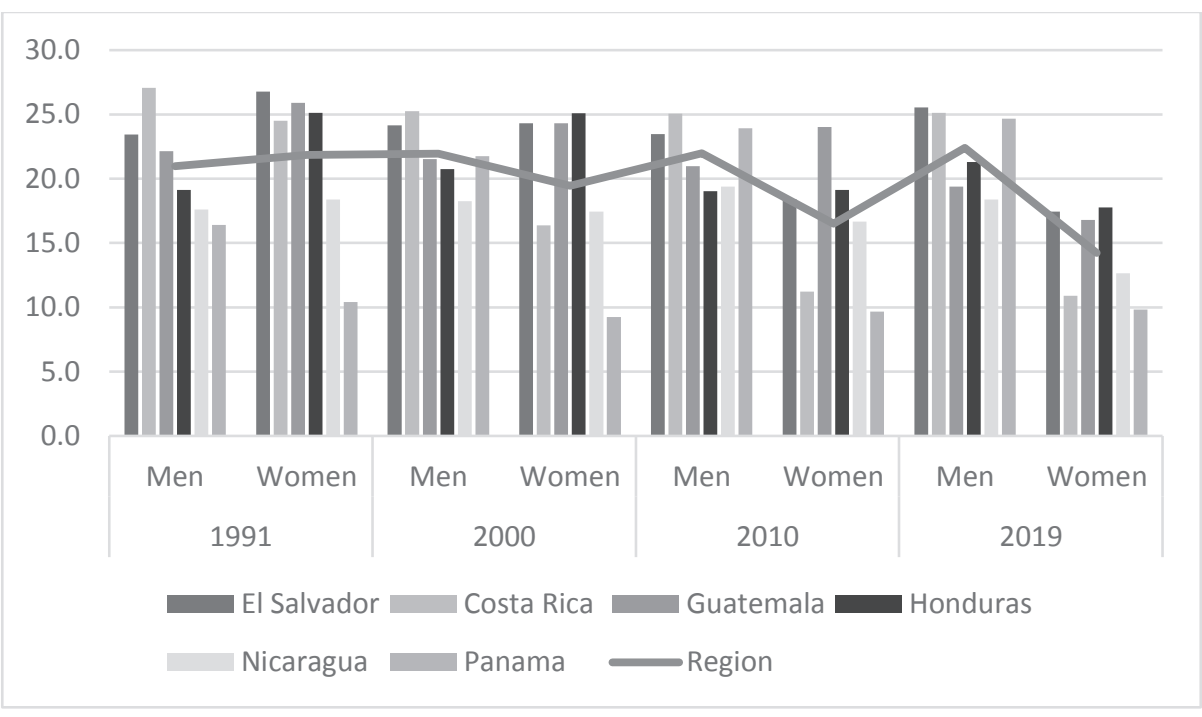

Source: World Bank (2020d).

Figure 3. Central America: employment in industry as a percentage of total employment by gender (1991-2019)

As a result of the drop in agricultural and industrial employment (see Figures 2 and 3) and workers taking refuge in services (Figure 4), precarious employment, including self-employment, unpaid family employment and unregistered employment, has increased. Precariously employed workers are more likely to be underemployed, informally or casually employed, underpaid and to live in poverty, without access to health care or social protection. According to the International Labour Organization (ILO), women are more susceptible to this risk (ILO, 2018). Concretely, 40 per cent of Central American women are in highly precarious occupations (see Figure 5). The situation of working women is especially critical in the region's northern countries, like Honduras, where vulnerable employment affects more than half of all working women. Nicaragua is in second place, followed by Guatemala and El Salvador. According to a report prepared by Oxfam Intermón: 
Close to 20 per cent of employed women in Central America work in the manufacturing sector. The rest work in commerce (41per cent of all employed women) and in community, social or personal services (32 per cent). Within manufacturing, many women work in maquiladora companies or in duty-free zones (approximately 263,000 women, 58 per cent of the sector's total labour force) that are mostly and/or basically associated with the garment industry (Oxfam Intermón, 2015: 4).

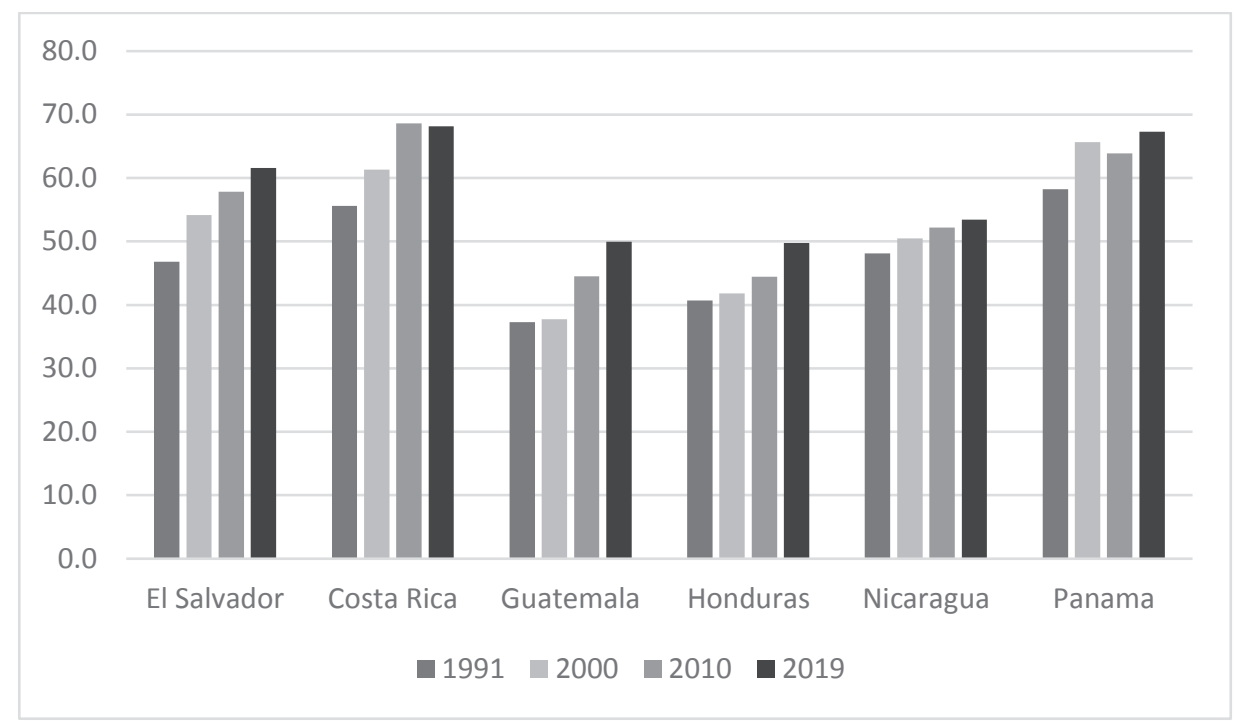

Source: World Bank (2020e).

Figure 4. Central America: employment in services as a percentage of total employment

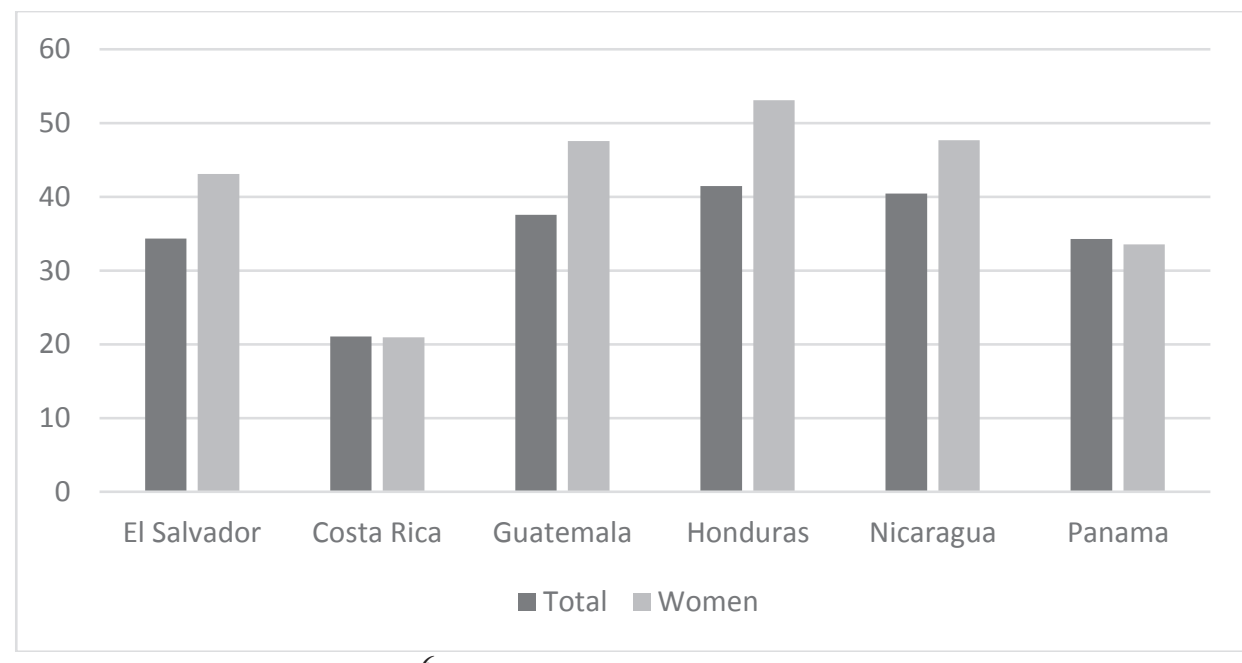

Source: World Bank (2020f). ${ }^{6}$

Figure 5: Central America: vulnerable employment as a percentage of total employment (2018)

\footnotetext{
${ }^{6}$ The notion of "vulnerable employment" used by the World Bank includes contributing family workers and self-employed workers as a percentage of total employment. Even if this category is more restrictive than the category of precarious employment that I used above, it provides an approximation to the problem of precarity in the region.
} 
The occupational disadvantages of women in Guatemala, El Salvador and Honduras account for the high degree of feminisation of labour migration, evidenced since 2018 by the enormous presence of women and their households in the so-called migrant caravans from these countries seeking to enter the United States.

\section{Central American Migration and Labour Corridors}

Migration trajectories in Central America cannot be strictly divided into periods. In the twentieth century, migration included the politically, economically and environmentally displaced. In the 1980s, civil wars and political repression caused the mass migration of refugees and displaced people from Nicaragua, El Salvador, Guatemala and Honduras. Approximately a quarter of a million displaced people and refugee applicants spread across Costa Rica, Nicaragua, Belize, Guatemala and Mexico (Aguayo, 1985). Starting in the 1990s, the region became part of a global system of labour supply through migration (Sassen, 1988; Castles and Miller, 1998; Robinson, 2004).

In 1990, there were almost 2.5 million international migrants from Central America in countries both within and outside the region. Migration boomed, with more than 25 per cent growth between 2005 and 2010, reaching an accumulated 3.8 million migrants in 2010. This was more than 50 per cent higher than the number of migrants in 1990. Even though the growth of migration started to slow down in 2010, preliminary data show the number of migrants in mid2019 was almost twice that of the 1990s (see Table 2 and Figure 6). Migrants, close to five million people in the period 2015-2019, account for 10 per cent of all inhabitants in the region. Of those captured by official statistics in the receiving countries, 92 per cent came from four of the region's seven countries: Guatemala, El Salvador, Honduras and Nicaragua (Table 3).

The Central American migratory flows are divided into two main labour corridors. ${ }^{7}$ The first is an extra-regional, northern corridor, with the United States as the main centre of attraction drawing migration mainly from Guatemala, El Salvador and Honduras. ${ }^{8}$ With 3.7 million Central Americans, this corridor attracts about 80.1 per cent of all Central American migrants. Salvadoreans constitute the largest community of Central Americans in the United States, at 38.2 per cent of all Central American migrants worldwide. Guatemalans, at 28.6 per cent, are the second largest, and Hondurans, with 17.5 per cent, are third. ${ }^{9}$ The second is an intraregional, southern corridor, which starts in Nicaragua and has Costa Rica as the main destination. This second corridor includes 330000 Central American migrants, representing 7 per cent of all Central American migrants worldwide (Table 3) but 64 per cent of all intraregional migrants (Morales-Gamboa, 2020). Intraregional corridors between bordering countries intersect with, and at the same time are part of, the corridor to the United States. Some workers also move through these corridors to reach intraregional labour markets, but the majority transit to the extra-regional market. These movements have often been overlooked in labour migration studies (Acuña et al., 2011; MoralesGamboa, 2018).

\footnotetext{
${ }^{7}$ Though both Belize and Panama belong to the region and constitute centres of attraction for intraregional migrants, they are of less significance in the context analysed here.

8 These three countries are often referred to as "the Northern Triangle". I avoid the label because of its geopolitical connotations.

${ }_{9}$ There are also migrants from other Central American countries in the corridor to the United States, but the majority are from Guatemala, El Salvador and Honduras.
} 
Table 2. Central American immigration growth rate by country of origin (1990-2019)

\begin{tabular}{|c|c|c|c|c|c|c|}
\hline \multirow{2}{*}{$\begin{array}{c}\text { Country of } \\
\text { origin }\end{array}$} & \multicolumn{7}{|c|}{ Interval } \\
\cline { 2 - 7 } & $\mathbf{1 9 9 0 - 1 9 9 5}$ & $\mathbf{1 9 9 5 - 2 0 0 0}$ & $\mathbf{2 0 0 0 - 2 0 0 5}$ & $\mathbf{2 0 0 5 - 2 0 1 0}$ & $\mathbf{2 0 1 0 - 2 0 1 5}$ & 2015-2019 \\
\hline Belize & 16.18 & 14.91 & 7.63 & 10.48 & 10.33 & 7.73 \\
\hline Costa Rica & 22.54 & 23.72 & 12.29 & 12.10 & 4.88 & 7.79 \\
\hline E1 Salvador & -24.86 & 1.71 & 17.91 & 19.49 & 13.24 & 5.69 \\
\hline Guatemala & 32.65 & 26.18 & 26.43 & 25.52 & 20.99 & 7.70 \\
\hline Honduras & 57.60 & 38.71 & 31.25 & 30.84 & 24.36 & 9.52 \\
\hline Nicaragua & -0.85 & 14.57 & -13.03 & 39.86 & 6.06 & 5.39 \\
\hline
\end{tabular}

Source: UNDESA (2020).

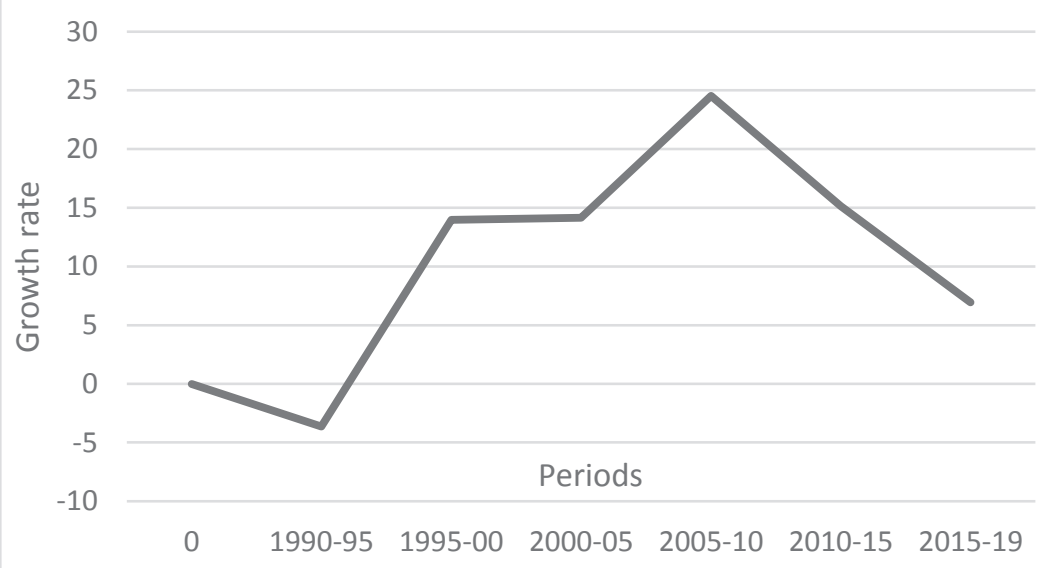

Source: UNDESA (2020). Base year 1990.

Figure 6: Migration from Central America (1990-2019)

Table 3. Central American migrants by main destination, 2019

\begin{tabular}{|l|c|c|c|c|c|}
\hline \multicolumn{1}{|c|}{$\begin{array}{c}\text { Country of } \\
\text { Origin }\end{array}$} & Total & $\begin{array}{c}\text { United } \\
\text { States }\end{array}$ & Costa Rica & $\begin{array}{c}\text { Rest of the } \\
\text { Region and } \\
\text { Mexico }\end{array}$ & $\begin{array}{c}\text { Rest of the } \\
\text { World }\end{array}$ \\
\hline Belize & 68,144 & 58,472 & 141 & 3,797 & 5,734 \\
\hline Costa Rica & 150,400 & 99,285 & 0 & 25,768 & 25,347 \\
\hline El Salvador & $1,600,739$ & $1,429,155$ & 14,104 & 45,852 & 111,628 \\
\hline Guatemala & $1,205,644$ & $1,070,743$ & 2,699 & 61,414 & 70,788 \\
\hline Honduras & 800,707 & 655,995 & 3,981 & 50,391 & 90,340 \\
\hline Nicaragua & 682,865 & 302,845 & 296,541 & 42,464 & 41,015 \\
\hline Panama & 161,107 & 125,329 & 11,592 & 3,278 & 20,908 \\
\hline Total & $4,669,606$ & $3,741,824$ & 329,058 & 232,964 & 365,760 \\
\hline Percentage & 100.0 & 80.1 & 7.0 & 5.0 & 7.8 \\
\hline
\end{tabular}

Source: UNDESA (2020). 
About 4.1 million Central Americans, representing 87.1 per cent of all Central American migrants worldwide, live in the United States and Costa Rica. Most of them are people of working age, equivalent to almost 20 per cent of the entire active labour force in Central America. This contingent constitutes a central component of the transnational labour force in the cross-border markets of both Costa Rica and the United States. The countries of origin of these migrant workers have become dependent on the remittances they send to their families (Orozco and Yansura, 2013): in 2018, remittances amounted to 8 per cent of the GDP of the countries of the region considered together, but an astounding 78 per cent of the GDP in El Salvador, 60 per cent in Honduras and 51 per cent in Guatemala (OIM, ACNUR and SICA, 2019). Yet, workers in both corridors share the disadvantages of having to become integrated into labour markets in their destination countries under precarious conditions.

\section{Spatial fragility and the corridors of Central American workers}

As I have mentioned above, the concept of corridor comprises spatial, regulatory and labour dimensions. I have identified fragility as the inability to claim effective protection of rights within a given territory. Understood in this way, fragility can be manifested in all of the three dimensions.

In the case of the spatial dimension, two situations are particularly relevant to assess the fragility migrants are subjected to within the two corridors I analyse in the paper. The first is connected to the political geographies of the corridors themselves, and the second to the risks associated with mobility within the two corridors, in particular the insecurity, violence and the negation of rights migrant workers are subjected to.

With regard to the first aspect, the corridor to the United States is the largest in the world. ${ }^{10}$ The distance and difficulties of the routes differ between this corridor and the intraregional one, as in addition to crossing Central American borders, the US corridor involves crossing both Mexico's southern border with Guatemala and its northern one with the United States. There is a dearth of reliable data regarding the number of people moving along this corridor into the United States, not only because of their condition as undocumented but also, and very importantly, because there are no reliable statistical data collection systems within the transit countries.

The region encompassed by Guatemala, El Salvador, Honduras, Belize and Mexico, as well as the borders between them, are the key constituents of the spatial dimension of the corridor towards the United States (Morales-Gamboa, 2018). Notwithstanding the measures in place for the control of borders between the countries of origin and transit (Villafuerte, 2020; Feldmann, 2020; Sandoval, 2020) and the various agreements Central American countries and Mexico have reached with the United States, borders between countries in this region continue to be very porous. This porosity enables an intense intraregional labour mobility between Guatemala and Mexico, Guatemala and Belize, Nicaragua and Honduras, and also allows for the confluence of migrants into the corridor towards the United States.

Mexico is a critical site in the corridor towards the United States. For instance, by 2014, there were 392000 registered entries, with annual averages remaining above 300000 between 2014 and 2016 (Rodríguez, 2016). The Unit for Migration Policy in the Office for Home Affairs reported that 149812 undocumented Central American migrants were detained in 2919, most of them from Honduras, Guatemala and El Salvador (Secretaría de Gobernación, 2020). Mexico is not only the unavoidable place of transit, but for many Central American migrants it is also the country blocking

10 "The US has been the main country of destination for international migrants since 1970. From then on, the number of foreign-born people residing in the country has more than quadrupled - from less than 12 million in 1970, to close to 51 million in 2019" (IOM, 2019: 25). 
their entry into the United States as the border between these two countries has become increasingly tight. Some of these migrants remain stranded in Mexico, others are deported to their country of origin (Hernández López and Pineda Velarde, 2018). For those migrants who remain in Mexico, survival depends on informal, temporary and always poorly paid jobs, or the support of various solidarity religious and civil society organisations (OIT, 2016; Rodríguez, 2018).

In contrast to the corridor to the United States, the southern corridor to Costa Rica is characterised by the proximity and contiguity between the countries of origin and destination. Beyond the scale of the migration flow, the corridor is also markedly shorter and the borders within it are less challenging. The Nicaragua-Costa Rica corridor is more porous than the northern corridor and does not involve other countries as transit territories. Most immigrants move from Nicaragua to Costa Rica, countries which share a number of social and cultural ties. ${ }^{11}$

Spatial fragility in the corridors is also associated with the insecurity and violence that operate at both domestic and foreign scales. Insecurity, violence and the lack of protection mechanisms are characteristic of the transit through the US corridor. There are high levels of violence in many places along the migratory route; assault, extorsion and rape are common, and many migrants have been murdered (Rodríguez, 2016; Canales and Rojas, 2018; CEPAL, 2018; Morales-Gamboa, 2020). The criminality that migrants are escaping from does not remain in the territories of origin; criminal groups have taken over the transit routes within Central America and Mexico, and this corridor has become one of the world's most dangerous (Humanitarian Practice Network, 2017).

Since the mid-2000s, the resurgence of new manifestations of violence caused by transnational criminality in Guatemala, El Salvador and Honduras, and the application of misguided law-andorder policies in these countries has led to a crisis of public security that further deteriorated the living conditions of the population (Ten Velde, 2012). At the same time, corruption, civic distrust of political institutions and a largely inefficient state stimulated the uprooting of masses of the population that began to identify the state itself as their adversary (Waxenecker, 2019). According to a report commissioned by the World Bank, the combination of high levels of criminality, drug trafficking, territorial control by criminal organisations, institutional weakness and high levels of corruption have dampened the hopes of a rebirth of the region following the end of its civil wars (Serrano-Berthet and López, 2011).

The corridor to Costa Rica does not exhibit the same degree of insecurity and criminal violence described above. After the peace agreements of the 1990s, Nicaragua achieved relative political stability and the country was comparatively free from the violence and crime that prevailed among its northern neighbours. However, starting in 2018, growing social unrest in Nicaragua has been met with an increasingly authoritarian response from the government, which is very likely to act as one more incentive for migration into Costa Rica if historical patterns provide some insight about the future.

\section{Regulatory fragility and the vulnerabilities of migrant workers}

Fragility is also connected with the mechanisms of migration control and its results, which affect the conditions of migrant workers in both corridors. Despite the contributions of the migrant labour force both in the destination markets as workers, and their countries of origin by way of remittances, the lack of effective rights protection increases migrants' vulnerability. Moreover, under the pressure from the United States, Mexico and some Central American countries have adopted new regulations and agreements that further increase the precarity of migrants as they

${ }^{11}$ There is also immigration from other countries to Costa Rica - Cuba, Haiti and extracontinental flows which uses this corridor and the other Central American countries as a transit route to the United States. 
move through the corridors.

Despite the imposition of entry restrictions by destination countries, migration has not stopped. In the case of the United States, restrictions started in the mid-1980s with the passing of several legal reforms: the Immigration Reform and Control Act (IRCA) in1986 that imposed controls on irregular migration and sanctioned employers who hired unauthorised labour; and the Illegal Immigration Reform and Immigration Responsibility Act (IIRIRA) in 1996 that imposed penalties on undocumented immigrants who commit crimes or who stay unlawfully in the United States, and allowed for the deportation of undocumented immigrants who committed a misdemeanour or a felony. They continued during the 2000s and more recently the Trump Administration (2017-2021) adopted a clear anti-immigration stance (Pierce and Selee, 2017; Martin, 2020). In a similar fashion, in Costa Rica controls started in the 2000s (Morales-Gamboa, 2008) but did not succeed in discouraging unauthorised workers from entering the country.

The demand for cheap labour has been key for both the United States and Costa Rica. While Mexican and Central American workers have satisfied this demand in the case of the United States (Haas, Castles and Miller, 2020), in Costa Rica this demand has been mostly satisfied by Nicaraguans. In both cases, policies aimed at dissuading employers from hiring unauthorised migrant workers have been weak and usually not enforced. This is why Central American migration did not stop after the hardening of entry policies implemented from 2001 in the wake of terrorist attacks in New York and Washington. On the contrary, the number of Central Americans in the United States experienced its largest growth during the 2000s.

The literature on US migration policy is broad (Macias, 2016; Feldmann, Bada and Schutze, 2019; Meissner and Gelatt, 2019; Narea, 2019; Goodman, 2020; Gramlich and Bustamante, 2020; MacNamara, 2020). However, the effects of these policies on the dynamics of the corridor, rather than only on the US territory and labour market, have not received enough attention. For example, the most important effect of policy changes in destination countries is the externalisation of migration controls, which has produced a shift of regulations from the US domestic realm to the corridor, thus transforming national policies into transnational control devices. ${ }^{12}$

The externalisation of migration controls has become tantamount to the externalisation of borders ${ }^{13}$ and has included cooperation agreements between the United States and Mexico, and the United States and Central American countries, with the purpose of increasing police surveillance over borders in Mexico and Central America and preventing migrants from arriving into the United States. In this line, the Mexican government implemented the "South Border Program" (Programa Frontera Sur) in mid-2014 to control migratory flows from Central America to the United States (Castañeda, 2016). With this, the Mexican government sought to "regulate Central American migration and improve border infrastructure to boost development and security, improve the coordination between Mexican agencies, and between Mexico and Central American governments, and protect migrants, guaranteeing the respect of their rights" (Isacson, Meyer and Smith, 2017: 7).

However, the programme did not improve either overall conditions or the security of the southern border. Nor did it strengthen migrants' human rights. Rather, from 2014, it led to an increase in the number of migrants detained by Mexican authorities. Migration has not stopped but spread across new paths, some of them more dangerous. Migrants have become more exposed to

\footnotetext{
${ }^{12}$ For a discussion of the externalisation of migration controls, see Frelick, Kysel and Podkul (2016).

${ }^{13}$ In 2012, Alain Bersin, then Assistant Secretary for International Affairs and Chief Diplomatic Officer of the Department of Homeland Security said, "The Guatemalan border with Chiapas is now our southern border" (see Treviño, 2012).
} 
human rights violations and to the action of criminal groups that control transit territories. Research conducted by the US-based think tank Rand Corporation estimated the revenues obtained by the operators of the smuggling services in 2017 may be as high as $\$ 2.3$ billion (Greenfield et al., 2019). This lucrative activity, in turn, has created opportunities for corruption and complicity on the part of police agents and other authorities in transit countries.

The absence of regulation enabling some protection to migrant workers is a characteristic of Central American borders. The Central America Free Mobility Agreement (Convenio Centroamericano de Libre Movilidad, CA 4) signed by Guatemala, El Salvador, Honduras and Nicaragua, expedites the transit of some groups, for example tourists and business travellers (Morales-Gamboa, 2018). However, while it protects the free circulation of some people, it fails to acknowledge the particular circumstances of migrant workers. This lack of common regulatory criteria shared by Central American countries to protect migrant workers is one of the factors that account for the growing fragility of these workers in the region (Morales-Gamboa, 2013; OIT, 2016).

With respect to the southern corridor, Costa Rica does have a more defined regulatory framework but instability and political conflict in Nicaragua combined with a long period of border tensions between both countries have resulted in regulatory voids that increase the fragility of undocumented migrant workers. The regulation of labour migration in Costa Rica is subordinated to general migration regulations. Although migration rules allow for the Ministry of Labour to participate in establishing criteria for the entry of both permanent and temporary workers, the changing dynamics of the labour market create ongoing imbalances between internal labour demand and the administrative measures through which it is to be addressed. Except for conditions set forth in the 2010 General Law on Migration and Alien Affairs, which regulates the entry, stay and departure of foreigners in Costa Rican territory, there are no other legal standards regulating labour migration, nor is there a general employment policy or one that applies to migrant workers.

Summarising, the nature of regulatory policies together with the rising criminalisation of migration (Stumpf, 2006; MacNamara, 2020), the illegalisation of the migrant labour force and the weakening of state authority in transit countries are, in my view, key new features defining survival migration in Central America. The loss of rights does not only take shape in workers' countries of origin or destination but is a phenomenon that is reproduced and intensified in the corridors. Even though this loss is more visible in the corridor to the United States, it is also a feature of the southern corridor, in both cases a result of the relationship between geography (distance and border framework), changes in policy, normative gaps and the risks associated with migration routes.

\section{Labour fragility: corridors as conduits of precarity}

Fragility is not only the reproduction of labour precarity from migrants' countries of origin in their destination countries. Neither is it a fortuitous situation that migrant workers encounter when they arrive in these destination countries. It is not a feature of migrant workers or something inherent to migration either. It is the always changing result of complex interactions between the geography of corridors, legal and regulatory frameworks, and the nature of the segments of labour markets that migrants are likely to occupy.

"Legal" migration is not an option for the majority of Central American migrants. This is why they, as many other unauthorised migrants in the world, are exposed to the action of illegal migrant trafficking networks (IOM, 2019). That reminds us that "the business of moving people across borders for profit, is a sordid and dangerous enterprise, often placing lives and well-being at serious risk" (Gallagher, 2015: 56).

Workers' subordination to these networks as well as the risks associated with the travel are 
expressions of the devaluation and the overexploitation of the labour force that starts before workers are hired in the destination country. Hiring agencies, mediators and even employers complicit with government officials are part of these complex trafficking networks of unauthorised migrants, many of whom are victims of human trafficking (OIT, 2016). From this point of view, corridors are not only the terrain for the transit of workers toward their destination country; they are also a series of spaces - local territories, countries and their borders - in which workers who come from labour markets characterised by precarity face new situations of loss of rights and deterioration of living conditions that intensify precarity before they arrive in the host country. In addition, low levels of qualifications and education of migrant workers set them in a particularly vulnerable position. Hence, workers tend to get the lowest quality jobs in the destination market even though migration often entails better living conditions for workers' families in the new country.

These factors account for the problems migrant workers encounter when they join US labour markets. First, many migrants are undocumented. Data from the Pew Research Center show that the number of undocumented Central American migrants grew from 1.5 to 1.9 million workers between 2014 and 2019 while the number of undocumented migrants from other parts of the world fell (Passel and Cohn, 2019). This group includes many migrants who are in the country under precarious migratory conditions - that is, they have temporary permits, they are beneficiaries of the Deferred Action for Childhood Arrivals or are refugee applicants. Second, many migrants have low education levels and qualifications. Half of all Central American workers 25 years of age or older have not completed secondary school (Budiman, 2020). Equally important, the Central American migrant labour force is mostly comprised of low-skilled workers. Finally, many migrants have difficulty speaking and writing English (O’Connor, Batalova and Bolter, 2019; Budiman, 2020). Education and the command of English are two of the main predictors of access to better quality jobs and better salaries.

In the United States, Central American men work mostly in services, agriculture and construction, while most women work in private homes, textile activities and clothing, and leather manufacturing. The participation in construction and services connected to the food industry which are considered gateway occupation into the US labour market - is much higher among more recent Central American migrants, approximately 29 per cent and 18 per cent respectively (Orrenius and Zavodny, 2015: 7). According to Desilver (2017), who relies on a Pew Research Center analysis of government data, the activities in which Central American workers are engaged are similar to those of all undocumented immigrants, such as agriculture (26 per cent of the undocumented), followed by cleaning and maintenance work (16 per cent), and construction and extraction (15 per cent).

Central American migrant workers have the lowest salaries when compared with local workers and other migrants to the United States. In 2017 the income of Central American workers was approximately $\$ 46000$, compared to $\$ 56700$ for all foreign-born workers, and $\$ 60800$ for USborn workers (O’Connor et al., 2019). Likewise, the lack of legal migration status combined with poor-quality and low-income jobs makes it more difficult for workers to access health care services. Almost 40 per cent of Central American immigrants in the United States lack access to health care, while 20 per cent of the migrants from other parts of the world and 7 per cent of US-born individuals confront the same problem. Closely connected with the access barriers to health care coverage, Central American workers have been among the groups of foreigners most vulnerable to COVID-19 infection and least likely to receive medical care in the United States (Open Society Foundations, 2020).

In Costa Rica, the principal characteristic of the migrant labour market is also its high volume 
of undocumented workers. Even though there are no up-to-date figures of undocumented workers in the country, it is safe to say that the hiring of these workers is a widespread practice among both large and small employers in a context of weak state supervision and high circulation of workers between Nicaragua and Costa Rica (Morales-Gamboa, 2013). A low level of education is a characteristic of this population as well. More than 80 per cent of Nicaraguans in Costa Rica have not completed secondary school, and they are also among the immigrant groups with the lowest number of people who have completed primary school.

Even though Costa Rican and Nicaraguan workers share demographic and cultural features, the latter tend to work in sectors considered as "ethnic niches" of Costa Rican labour markets, namely, manual, low-skill and low-wage jobs. Commerce, service, agriculture and construction are the sectors that absorb the foreign workers (more than 90 per cent of whom are from Nicaragua) in Costa Rica. In 2016, for example, and with a similar tendency in the years to follow, 15.8 per cent of foreigners were employed in wholesale and retail trade and in auto repair shops, 14.3 per cent in agriculture, 13.6 per cent in paid domestic service and 14.3 per cent in construction. Men dominate in construction work, while women dominate in domestic services, trade, restaurants and hospitality services related to tourism. Though labour market records show that agriculture has less weight than other sectors, the seasonal harvests of coffee, citrus fruits, sugarcane and other products make heavy use of Nicaraguan migrants, with the demand for labour ranging between 80000 and 100000 workers, depending on the productivity of each harvest cycle. Among the jobs performed by Nicaraguans, basic occupations in the branches of activity mentioned above and in commerce and services predominate, employing almost 75 per cent of Nicaraguan workers in Costa Rica (Morales-Gamboa, 2020).

The average income of Nicaraguan workers in Costa Rica is 10 per cent lower than that of Costa Rican and other Central American workers (Morales-Gamboa. 2020). Even though access to public health services is not formally conditioned by workers' migratory status, membership costs, combined with red tape and legal voids have created formal and informal access barriers to health care for migrant workers (Fouratt and Voorend, 2019). The COVID-19 pandemic made this problem painfully evident as a significant number of agro-industrial export facilities were hiring undocumented Nicaraguan workers who lacked access to health care and became exposed to infection with COVID-19 (Murillo, 2020); at the same time they were defenceless in the face of immigration provisions to expel them from the country and the simultaneous closure of borders to the entry of temporary workers.

As discussed in this section, labour fragility is the dynamic outcome of the combination of several factors which account for the risks and loss of rights workers experience in corridors and destination labour markets, which in turn limit workers' prospects of overcoming labour precarity. The vulnerabilities to which workers are exposed are produced and reproduced within their own country of origin and very often only deepened by the conditions under which the transit to the destination countries is undertaken. Thus, corridors trap migrant workers into conditions of increased risk while simultaneously failing to provide the protection of rights that might give them options to counter their vulnerabilities. By doing so, they function as the spaces through which labour fragility is maintained and transferred from the country of origin to those of destination.

\section{Conclusions: The Heightened Vulnerability of Migrant Workers}

Under the concept of fragility, I have discussed the spatial, regulatory and labour features of migrant workers' corridors to the United States (the northern corridor) and Costa Rica (the southern corridor), and the ways in which these features reproduce the vulnerability of survival 
migration and precede migrant workers' precarious insertion into destination labour markets. Migrants lack the resources to counteract the perverse effects of the journey. In many cases they lack migration documents, are exposed to legal repression and normative voids, and are vulnerable to the arbitrariness of human trafficking networks associated with organised crime, police corruption and overall lack of protection.

As I have shown, Central American migration is shaped by several factors in the territories of origin that experienced economic changes in the 1990s under the neo-liberal restructuring and the programme of free-market capitalism (Robinson, 2003). This new model has entailed the growth of the service sector, especially informal trade, as the main sources of employment in domestic labour markets. This sector is characterised by the prevalence of precarious employment with a high participation of family and self-employed workers. Similarly, this has been the context for the creation of a cheap labour force. This explains the rapid growth of Central American migration between 2000 and 2010. Low-quality employment has also resulted from the effects of the climate crisis, rising insecurity associated with the control exercised by organised criminal networks over territories and communities, the weakness of the state, impunity and corruption. These are the main expressions of survival migration that are at the root of the risks and setbacks experienced by migrants (Morales-Gamboa, 2020).

Migration does not address the historical fragility that is at its origins. Fragility is associated, among other factors mentioned before, with structural economic changes that have reduced the capacity of agriculture and manufacturing to retain jobs. And while jobs in personal and community services and commerce have grown, informality, vulnerable employment and job precarity have nonetheless seen sharp increases.

In this context, job losses, under the effects of global restructuring changes in the region, became the critical structural cause of migration, leading to the rapid growth of the Central America-United States corridor in the 1990s, as part of major changes in the dynamics of transnationalised labour supply. However, the characteristics of the corridor go beyond this labour dimension. In this historically conflict-ridden territory, the reappearance of violence in mid-2000s, related to organised crime, state corruption and political repression, exacerbated the fragility caused by historical inequalities. Consequently, migration ceased to be only an option, becoming instead forced displacement for new groups, as the case of Nicaraguans after 2018 and other Central Americans since the mid-2000s.

The disadvantages of the social and political systems, deteriorating labour markets and workers' vulnerable conditions in their countries of origin, far from improving, only worsens with migration, both in the corridor and in the destination countries. In the two corridors analysed here, Central American migrant workers have been absorbed in low-skilled and poorly paid occupations. This situation places Central American workers in the US labour market in highly adverse conditions, with greater poverty and instability than other social groups. These conditions are similar, albeit with their own particularities, in the corridor between Nicaragua and Costa Rica, where Nicaraguans are the most significant foreign labour force. In addition to their irregular migration status, these workers work in the service, commerce, construction and agriculture sectors, where they lack labour rights and are exposed to increasing precarity, over-exploitation and low wages.

Analyses of these labour corridors allow us to broaden local perspectives regarding domestic labour markets, to note the transnational or cross-border interdependence of market characteristics and labour inequalities. Domestic inequalities become regional and transnational and, in countries like those in Central America, that are so highly dependent on migration, reveal the need to situate labour issues in terms of how social relations are organised in today's challenging and unequal 
global context.

Finally, fragility operates in the three dimensions of corridors to produce and reproduce the vulnerability of survival migration. It also contributes to the precarisation of the labour force before workers join labour markets in the destination countries. The outcome of this survival migration is the devaluation of the labour force, not only because it is made illegal but also because workers' rights are denied. State weaknesses and the absence of protection expose workers to abuses on the part of criminals and authorities, and make them vulnerable to police corruption in the origin, transit and destination territories. Corridors thus operate as devices for the devaluation of the migrant labour force. They contribute to the loss of citizenship ties and the denial of rights, in spite of the contribution these workers make to labour markets both in their countries of origin and destination. Labour precarity is also related to new forms of migratory vulnerability: undocumented labour migrants not only face obstacles in their attempts to achieve a non-precarious insertion into the destination labour market, but they are also at constant risk of being deported from the destination country. The fragility of survival migration is a new expression of the overexploitation of labour - in this case, in the transnational realm in which migration corridors are located.

\section{References}

Acuña, G., K. Voorend, M. Alfaro, M. Smith and E. Herra (2011) Flujos migratorios laborales intrarregionales: situación actual, retos y oportunidades en Centroamérica y República Dominicana. Informe regional. San José, C.R.: OIM, OIT, MTSS, CECC SICA, OCLAD, Red de Observatorios del Mercado Laboral, AECID, 2011.

Aguayo, S. (1985) El éxodo centroamericano: consecuencias de un conflicto. Mexico: SEP.

Alvarez, M., M.E. Mira, E. Veliz, A. Ortega, C. Mendoza and J. Alemancia (2015) El extractivismo en América Central: Un balance del desarrollo de las industrias extractivas. Panamá: Fundación Friedrich Ebert para Costa Rica, Nicaragua y Panamá.

Bakewell, O. (2014) Relaunching migration systems. Migration Studies, 3(2): 300-318.

Bash, L., N. Glick Schiller and C. Szanton Blanc (1994) Nations Unbound: Transnational Projects, Postcolonial Predicaments, and Deterritorialized Nation-States. London: Gordon and Breach Science Publishers.

Betts, A. (2013) Survival Migration: Failed Governance and the Crisis of Displacement. New York: Cornell University Press. https://library.oapen.org/bitstream/handle/20.500.12657/ 30779/642723.pde?sequence=1 (accessed 14 July 2017).

Budiman, A. (2020) Key findings about U.S. immigrants. Pew Research Center, August 20. https://www.pewresearch.org/fact-tank/2020/08/20/key-findings-about-u-s-immigrants (accessed 20 April 2021).

Camus, M. (ed.) (2007) Comunidades en movimiento. La migración internacional en el norte de Huehuetenango. Guatemala: CEDFOG - INCEDES.

Canales, A. and M.L. Rojas (2018) Panorama de la migración internacional de México y Centroamérica. Serie Población y Desarrollo. Santiago: CEPAL. https://repositorio.cepal.org/bitstream/handle L11362/43697/1/S1800554 es.pdf(accessed 18 April 2020).

Castañeda, A. (2016) ¿Qué es el Programa Frontera Sur? Observatorio de Legislación y Política Migratoria. Bulletin No. 11, February 2016. https://observatoriocolef.org/wp-content/uploads/2016/06/BOLET\%C3 \%8DN-1-Alejandra-Casta\%C3\%B1eda.pdf (accessed 6 June 2021).

Castillo, M.A. (2000) Las políticas hacia la migración centroamericana en países de origen, de destino y de tránsito. Papeles de Población, 6(24): 133-157.

Castles, S. (2009) Development and Migration - Migration and Development. What Comes First? Global Perspective and African Experiences. Theoria: A Journal of Social and Political Theory, 56(121): 1-31. 
Castles, S. and M. Miller (1998) The Age of Migration. International Population Movements in the Modern World. New York: The Guilford Press.

Chaves-Groh, M (2017) Costa Rica en la migración regional, perspectivas recientes (2000-2014). Revista de Ciencias Sociales, III(57): 27-52.

Chestermann, S., M. Ignatieff and T. Takur (2005) Making States Work: State Failure and the Crisis of Governance. New York: United Nations University Press.

Cortés, A. (2003) Apuntes sobre las tendencias migratorias en América Central en la segunda mitad del siglo XX. Revista Reflexiones, 82(2). https://revistas.ucr.ac.cr/index.php/reflexiones/article/view/11374 (accessed 20 September 2006).

Comisión Económica para América Latina y el Caribe (CEPAL) (2014) Evolución del sector agropecuario en Centroamérica y la República Dominicana, 1990-2014. (LC/MEX/L.1175), México, D.F.

Comisión Económica para América Latina y el Caribe (CEPAL) (2018) Atlas of Migration in Northern Central America. Santiago: United Nations.

Desilver, D. (2017) Immigrants Don't Make Up a Majority of Workers in any U.S. Industry. Pew Research Center: FactTank News in the Numbers, 16 March 2017. https://www.pewresearch.org/facttank/2017/03/16/immigrants-dont-make-up-a-majority-of-workers-in-any-u-s-industry (accessed 28 July 2020).

Durand, J. (2016) El subsistema migratorio mesoamericano. In El sistema migratorio mesoamericano, edited by C. Heredia. Mexico: El Colegio de la Frontera Norte and Centro de Investigación y Docencia Económicas.

Feldmann, A. (2020) Centroamérica Políticas migratorias en Estados Unidos, México y la Unión Europea (2010-2019). Implicaciones para Centroamérica y los derechos humanos de las personas migrantes y refugiadas. Draft for the 2021 State of the Region Report, Programa Estado de la Región. http://repositorio.conare.ac.cr/handle/20.500.12337/7942 (accessed 6 July 2020).

Feldmann, A.E., X. Bada and S. Schutze (2019) New Migrations Patterns in the Americas: Challenges for the 21st Century. New York: Palgrave.

Frelick, B., I.M. Kysel and J. Podkul (2016) The Impact of Externalization of Migration Controls on the Rights of Asylum Seekers and Other Migrants. Journal on Migration and Human Security, 4(4): 190-220 https://www.hrw.org/news/2016/12/06/impact-externalization-migration-controls-rights-asylumseekers-and-other-migrants (accessed 6 June 2021).

Fouratt, C. and K. Voorend (2019). Esquivando prácticas privadas en el uso de los servicios de salud entre inmigrantes nicaragüenses en Costa Rica. Anuario de Estudios Centroamericanos, 45: 373-403.

Gallagher, A. (2015) Exploitation in Migration: Unacceptable but Inevitable. Journal of International Affairs, 68(2): 56-74.

García, Z. R. and M. Orozco (eds.) (2009) Migración internacional, remesas y desarrollo local en América Latina y el Caribe. México: Universidad Autónoma de Zacatecas/Inter-American Dialogue/Miguel Ángel Porrúa.

Glick Shiller, N. (2014) Twenty Years of the Transnational Migration Paradigm: Conjuncture, Temporality, and Agency. Paper presented to the Annual Meeting of the American Anthropological Association, Washington, DC, December 2-7.

Goodman, A. (2020) The Deportation Machine: America's Long History of Expelling Immigrants. Princeton, NJ: Princeton University Press.

Gramlich, J. and L.N. Bustamante (2020) What's Happening at the U.S.-Mexico Border in 5 Charts. Pew Research Center. $\quad$ https://www.pewresearch.org/fact-tank/2019/11/01/whats-happening-at-the-u-s-mexicoborder-in-5-charts (accessed 20 December 2020).

Greenfield, V.A., B. Nuñez-Neto, I. Mitch, J.C. Chang and E. Rosas (2019) Human Smuggling and Associated Revenues: What Do or Can We Know About Routes from Central America to the United States? Homeland Security Operational Analysis Center (HSOAC) / RAND Corporation. www.rand.org/t/RR2852 (accessed 24 July 2020). 
Haas, H. de, S. Castles and M. Miller (2020) The Age of Migration: International Population Movements in the Modern World. London: The Guilford Press.

Heredia, C. (2016) El sistema migratorio mesoamericano, Mexico: El Colegio de la Frontera Norte and Centro de Investigación y Docencia Económicas.

Hernández López, R. and M. Pineda Velarde (2018) Atrapados en la movilidad. Nuevas dinámicas de la migración y el refugio en México. Guadalajara: FM4 Paso Libre Dignidad y Justicia en el Camino A.C. https://fm4pasolibre.org/wp-content/uploads/2019/01/Atrapados-en-la-movilidad-2.pdf (accessed 15 February 2019).

Hoeffler, A., (2013) Out of the Frying Pan into the Fire? Migration from Fragile States to Fragile States. Thematic paper supporting the OECD DAC INCAF project Global Factors Influencing the Risk of Conflict and Fragility, Working Paper No. 8. https://www.oecd-ilibrary.org/development/out-of-the-frying-paninto-the-fire-migration-from-fragile-states-to-fragile-states 5k49dffmipmv-en (accessed 16 April 2020).

Humanitarian Practice Network (2017) The Humanitarian Consequences of Violence in Central America. Humanitarian Exchange, Special Feature, No. 69, Overseas Development Institute, June.

International Labour Organization (ILO) (2018) World Employment and Social Outlook: Trends for Women 2018 - Global Snapshot. Geneva: ILO. https://www.ilo.org/global/research/global-reports/weso/trends-forwomen2018/WCMS 619577/lang--en/index.htm (accessed 27 April 2019).

International Organisation for Migration (IOM) (2019) World Migration Report 2020. Geneva: IOM. https://publications.iom.int/system/files/pdf/wmr_2020.pdf (accessed 21 June 2020).

Isacson, A., M. Meyer, and H. Smith (2017) La frontera sur de México. Seguridad, migración centroamericana y políticas estadounidenses, Informe de Investigación. Washington: WOLA Advocacy for Human Rights in the Americas.

Koonings, K. and D. Kruijt (2015) Violence and Resilience in Latin American Cities. London: Zed Books.

Macias, P. (2016) From Deportation to Prison: The Politics of Immigration Enforcement in Post Civil Rights America. New York: New York University Press.

MacNamara, R. (2020) The Criminalization of Immigration: Truth, Lies, Tragedy, and Consequences. London: Praeger.

Maquila Solidarity Network (2016) Las trabajadoras(es) de la industria maquiladora en Centroamérica. San Salvador: Maquila Solidarity Network. https://www.maquilasolidarity. org/sites/default/files/attachment/ Trabajadores de la maquila C.A 2016.pdf (accessed 27 July 2020).

Marc, A., A. Willman, G. Aslam and M. Rebosio with K. Balasuriya (2013) Societal Dynamics and Fragility: Engaging Societies in Responding to Fragile Situations. Washington, DC: World Bank. DOI: 10.1596/978-08213-9656-8.

Marroquín, A. (2014) La migración centroamericana. Apuntes para un mapa provisional. Estudios Centroamericanos, 69(736): 91-103.

Martin, P. (2020) President Trump and Migration at 3. Migration Letters, 17(1): 191-200.

Martin-Shields, C. (2017) State Fragility as a Cause of Forced Displacement. Identifying theoretical channels for empirical research, German Development Institute, Discussion Paper 30/2017. or http://dx.doi.org/10.2139/ssm.3087980.

Meissner, D. and J Gelatt (2019) Eight Key U.S. Immigration Policy Issues: State of Play and Unanswered Questions. Washington, DC: Migration Policy Institute.

Menjívar, C. (2000) Fragmented Ties. Salvadoran Immigrant Networks in America. Berkeley, CA: University of California Press.

Morales-Gamboa, A. (2007) La diáspora de la posguerra. Regionalismo de los migrantes y dinámicas territoriales en América Central. San José: FLACSO Costa Rica. 
Morales-Gamboa, A. (2008) Inmigración en Costa Rica, características sociales y laborales, integración y politicas públicas. Serie Población y Desarrollo No. 85. Santiago: Centro Latinoamericano y Caribeño de Demografía (CELADE) - División de Población de la CEPAL.

Morales-Gamboa, A. (ed.) (2010) Migraciones y derechos laborales en Centroamérica: características de las personas migrantes y de los mercados de trabajo. San José: FLACSO Costa Rica.

Morales-Gamboa, A. (2013) Tendencias de las migraciones en América Central, inserción laboral de trabajadores migrantes y regímenes de protección sociolaboral. In Migraciones y mercados laborales en Centroamérica, edited by Secretaría de la Integración Centroamericana (SISCA). Serie de Políticas Sociales 10. San Salvador: Consejo de la Integración Centroamericana y Observatorio Centroamericano del Desarrollo Social.

Morales-Gamboa, A. (2014) Corredores migratorios y cambios en los medios de vida rurales en América Central. ALASRU. Nueva época. Análisis latinoamericano del mundo rural, 10: 107-126.

Morales-Gamboa, A. (2018) Fragilidad de los corredores transfronterizos de trabajadores temporales. Territorios, mercados de trabajo y dispositivos de la gobernanza en Centroamérica. In El territorio como recurso: movilidady apropiación del espacio en México y Centroamérica, edited by O.M. Hoffmann and A. MoralesGamboa. San José: FLACSO Costa Rica.

Morales-Gamboa, A. (2020) Migraciones internacionales, refugiados y desplazamientos internos en Centroamérica: factores de riesgo e instrumentos para fortalecer la protección de los derechos humanos. San José: Programa Estado de la Región. http://repositorio.conare.ac.cr/handle/20.500.12337/7956 (accessed 23 October 2020).

Morales-Gamboa, A. and C. Castro-Valverde (2002) Redes Transfronterizas: Sociedad, empleo y migración entre Costa Rica y Nicaragua. San José: FLACSO Costa Rica.

Muggah, R. (2014) Deconstructing the Fragile City: Exploring Insecurity, Violence and Resilience. Environment \& Urbanization, 26(2): 345-358.

Murillo, A. (2020) Covid 19 se ensaña más contra población extranjera: ahora conforma el 26 por ciento de los casos. Universidad, 16 June 2020. https://semanariouniversidad.com/ pais/covid-19-se-ensana-mascontra-poblacion-extranjera-ahora-conforma-el-26-de-los-casos (accessed 16 June 2020).

Nagarajan, C., P. Benjamin, R. Lukas, F. Sylvestre, J. Vivekananda, M. Wall and S. Wolfmaier (2018) ClimateFragility Profile: Lake Chad Basin. Berlin: Adelphi.

Narea, N. (2019) Trump's Agreements in Central America are Dismantling the Asylum System as We Know It. Vox, 26 September 2019. https://www.vox.com/2019/9/26/20870768/trump -agreementhonduras-guatemala-el-salvador-explained (accessed 28 February 2020).

O'Connor, A., A. Batalova, and J. Bolter (2019) Central American Immigrants in the United States. Migration Information Source, 15 August 2019. https://www.migrationpolicy. org/article/central-americanimmigrants-united-states (accessed 3 January 2020).

Organización Internacional del Trabajo (OIT) (2016) La migración laboral en América Latina y el Caribe. Diagnóstico, estrategia y líneas de trabajo de la OIT en la Región. Lima: OIT, Oficina Regional para América Latina y el Caribe.

Open Society Foundations (2020) Covid 19 and Undocumented Workers. https://www.opensociety foundations.org/explainers/covid-19-and-undocumented-workers (accessed 19 August 2020).

Orozco, M. and J. Yansura (2013) Migration and Development in Central America: Perceptions, Policies, and Further Opportunities. Immigration Working Paper. Washington, DC: Inter-American Dialogue.

Orrenius, P. and M. Zavodny (2015) Los Centroamericanos en el Mercado Laboral de Estados Unidos: Tendencias Recientes e Impactos de la Política Pública, Policy Brief Series, CANAMID. Central America - North America Migration Dialogue, PB 03, CIESAS, McArthur Fundation and Georgetown University. http://www.canamid.org/publication? id=PB03 (accessed 14 July 2020). 
Oxfam Intermon (2015) Derechos que penden de un hilo. Zonas francas textiles frente a cooperativas de comercio justo. Oxfam Intermon. https://oxfamintermon.s3.amazonaws. com/sites/default/files/documentos/files/ DerechoQuePendenDeUnHilo.pdf (accessed 12 March 2016).

Pandit, K. (1994) Differentiating Between Subsystems and Typologies in the Analysis of Migration Regions: A U.S. Example. The Professional Geographer, 46(3): 277-408. https://doi.org/10.1111/j.00330124.1994.00331.x

Passel, J. and D. Cohn (2019) Mexicans Decline to Less Than Half the U.S. Unauthorized Immigrant Population for the First Time. Pew Research Center, 12 June 2019. https://www.pewresearch.org/facttank/2019/06/12/us-unauthorized-immigrant-population-2017 (accessed 3 October 2019).

Pierce, S. and A. Selee (2017) Immigration under Trump: A Review of Policy Shifts in the Year since the Election. Policy Brief. Washington, DC: Migration Policy Institute.

Pries, L. (2001) New Transnational Social Spaces. International Migration and Transnational Companies in the Early Twenty-First Century. London: Routledge.

Pries, L. (2017) La transnacionalización del mundo social. Espacios sociales más allá de las sociedades nacionales, México City: El Colegio de México.

Pröbsting, M. (2015) Migration and Super-exploitation: Marxist Theory and the Role of Migration in the present Period of Capitalist Decay. Critique. Journal of Socialist Theory, 43(3-4): 329-346.

Programa de Naciones Unidas para el Desarrollo (PNUD) (2005) Informe de Desarrollo Humano de El Salvador 2005. Una mirada al nuevo Nosotros. El impacto de las migraciones. San Salvador: PNUD.

Robinson, W. (2003) Transnational Conflicts. Central America, Social Change, and Globalization. London: Verso.

Robinson, W. (2004) A Theory of Global Capitalism. Production, Class, and State in a Transnational World. Baltimore, MD: Johns Hopkins University.

Rodríguez, E. (2016) Migración centroamericana en tránsito irregular por México. Nuevas cifras y tendencias. Technical Report, December 2016. CANAMID Policy Brief Series, PB14. Mexico: CIESAS.

Rodríguez, M.T. (2018) Estar de paso. Trayectorias centroamericanas en el centro de Veracruz, México. In El territorio como recurso: movilidady apropiación del espacio en México y Centroamérica, edited by O.M. Hoffmann and A. Morales-Gamboa. San José: FLACSO Costa Rica.

Sandoval, C. (ed.) (2020) Puentes, no muros: contribuciones para una politica progresista en migraciones. Buenos Aires y México: CLACSO y Fundación Rosa Luxemburg.

Sandoval, C. (ed.) (2016), Migraciones en América Central. Políticas, territorios y actores. San José: Editorial de la Universidad de Costa Rica, Instituto de Investigaciones Sociales.

Sandoval, J.M. (2007) Trabajadores migrantes de México, Centroamérica y el Caribe. Reserva laboral transnacional flexible del capitalismo norteamericano. In ¿Invisibles? Migrantes internacionales en la escena politica, edited by Imaz, Cecilia. México: Universidad Autónoma de México y SITESA.

Sassen, S. (1988) The Mobility of Labor and Capital. A Study of International Investment and Labor Flow. Cambridge: Cambridge University Press.

Secretaría de Gobernación (SEGOB) (2020) Sintesis 2020. Estadísticas migratorias. México: Unidad de Política Migratoria, Registro e Identidad de Personas. Subsecretaría de Derechos Humanos, Población y Migración.

Serrano-Berthet, R. and H. López (2011) Crime and Violence in Central America: A Development Challenge. Washington, DC: World Bank.

Sistema de la Integración Centroamericana (SICA), Organización Internacional para las Migraciones (OIM) and Alto Comisionado de la ONU para Refugiados (ACNUR) (2019) Hallargos del estudio sobre línea de base sobre migración y desplazamiento forzado en la región del SICA. Informe Regional, Julio 2019. Guatemala: Sistema de la Integración Centroamericana. 
Smith, D. and J. Vivekananda (2009) Climate Change, Conflict and Fragility. Understanding the Linkages, Shaping Effective Responses. London: International Alert. https://www.international-alert.org/sites/default/files/ publications/Climate change conflic t and fragility_Nov09.pdf (accessed 27 May 2019).

Stumpf, J. (2006) The Crimmigration Crisis: Immigrants, Crime, and Sovereign Power. American University Law Review, 56(2): 367-419. https://digitalcommons.wcl. american.edu/cgi/viewcontent.cgi?article $=1274 \&$ context $=$ aulr $($ accessed 4 February 2015).

Ten Velde, L. (2012) The Northern Triangle's Drugs-Violence Nexus: The Role of the Drugs Trade in Criminal Violence and Policy Responses in Guatemala, El Salvador and Honduras. Drugs \& Conflict Debate Papers, 19. Amsterdam: Transnational Institute. https://www.tni.org/my/node/1299? content language $=$ en $($ accessed 12 June 2020).

Treviño, M. (2012) Our Southern Border is Now with Guatemala. In Latina Lista. The smart nens source, 20 September 2012. http://latinalista.com/general/historic-partnership-agreements-signed (accessed 9 October 2020).

United Nations Department of Economic and Social Affairs (UNDESA) (2020) Population Division. International Migration. Workbook: UN_MigrantStockTotal_2019.xlsx. Table 1. https://www.un.org/en Ldevelopment/desa/population/migration/data/estimates2/estimates19.asp (accessed 5 May 2020).

Vertovec, S. (2004) Migrant Transnationalism and Modes of Transformation. International Migration Review, 38(3): 970-1001.

Viales, R. and D. Díaz. (2016) Entre el indentured labor y las remesas familiares. Movimientos de población desde y hacia América Central desde una perspectiva transnacional. Siglos XIX y XX”. In Historia comparada de las migraciones en las Américas, edited by P. Galeana de Valadés. México City: UNAM, Instituto de Investigaciones Jurídicas.

Villafuerte, D. (2020) La migración centroamericana y la Cuarta Transformación ¿̇hacia un nuevo paradigma de política migratoria? In Movilidad humana en tránsito: retos de la Cuarta Transformación en política migratoria, edited by M.E. Anguiano and D. Villafuerte. Buenos Aires: CLACSO.

Waxenecker, H. (2019) Políticas de Estado, desplazamiento forzado y migración: una mirada regional al norte de Centroamérica. San Salvador: Heinrich Böll Stiftung.

World Bank (2020a) Database. Agriculture, Forest, and Fishing, Value Added (\% of GDP). https://data.worldbank.org/indicator/NV.AGR.TOTL.ZS (accessed 14 July 2020).

World Bank (2020b) Database. Employment in Agriculture (\% of Total Employment) (modeled ILO Estimate). https://data.worldbank.org/indicator/SL.AGR.EMPL.ZS (accessed 1 July 2020).

World Bank (2020c) Database. Employment in Industry (\% of Total Employment) (Modeled ILO Estimate). https://data.worldbank.org/indicator/SL.IND.EMPL.ZS (accessed 1 July 2020).

World Bank (2020d) Database. Employment in industry (\% of Total Employment) (Modeled ILO Estimate. https://data.worldbank.org/indicator/SL.IND.EMPL.MA.ZS (male) and https://data.worldbank.org indicator/SL.IND.EMPL.FE.ZS (female) (accessed 1 July 2020).

World Bank (2020e) Database. Employment in Industry (\% of Total Employment) (Modeled ILO Estimate. https://data.worldbank.org/indicator/SL.SRV.EMPL.ZS. (accessed 1 July 2020).

World Bank (2020f) Database. Vulnerable Employment, Female (\% of Female Employment) (Modeled ILO Estimate). https://data.worldbank.org/indicator/SL.EMP.VULN.ZS (Total) and https://data.worldbank.org Lindicator/SL.EMP.VULN.FE.ZS (Female) (accessed 1 July 2020). 


\section{BIOGRAPHICAL NOTE}

Abelardo Morales-GamboA is professor of sociology at the Universidad Nacional of Costa Rica, and a senior research fellow at Facultad Latinoamericana de Ciencias Sociales (FLACSO) Sede Costa Rica. He has published on regional and territorial development, and on labour migration in Central America. He is co-editor (with Odile Hoffmann) of The Territory as a Resource: Mobility and Appropriation in Mexico and Central America (San José: FLACSO, IRD France and National University, 2018). [Email: Abelardo.morales.gamboa@una.cr] 